\title{
PEMANFAATAN AHP SEBAGAI MODEL DECISION SUPPORT SYSTEM PENENTUAN DESA POSDAYA
}

\author{
Rina Fiati, Tutik Khotimah
}

Program Studi Teknik Informatika, Fakultas Teknik, Universitas Muria Kudus Gondang Manis, Bae, PO.Box 53, Kudus, Telp.0291 43229, Fax (0291)437198

Email : rfiati003@yahoo.com, tutik.khotimah@gmail.com

\begin{abstract}
ABSTRAK
Millenium Development Goal's (MDG's), menyepakati delapan fokus pembangunan bagi negara-negara di dunia yaitu penghapusan kemiskinan dan kelaparan. Tahun 2010 anak perempuan dan laki-laki mendapatkan pendidikan dasar penuh, mempromosikan kesetaraan dan kematian bayi dan balita, menurunkan angka kematian ibu, memerangi penyakit menular (TBC, HIV/AIDS, malaria dan penyakit menular lainnya). Menjamin keberlangsungan lingkungan hidup dan meningkatkan kerjasama global. Maka pemerintah mencanangkan Pos Pemberdayaan Keluarga (Posdaya). Pengumpulan data disusun berdasarkan studi literatur, observasi dan wawancara, sehingga dihasilkan kriteria-kriteria dalam Posdaya. Selanjutnya kriteria tersebut diberi penilaian perbandingan berpasangan dengan AHP (Analitycal Hierarchy Process) untuk mencari bobot prior dengan skala penilaian antara 1-9. Hasil dalam penentuan desa posdaya menunjukan bahwa kriteria aspek ekonomi, pendidikan, kesehatan dan lingkungan merupakan kriteria utama dalam menentukan desa berbasis posdaya. Sistem yang dibangun dapat menghasilkan penilaian desa mandiri berbasis posdaya, rintisan posdaya atau belum adanya posdaya, berdasarkan akhir penilaian yang dihasilkan oleh sistem. Sehingga sistem ini diharapkan dapat membantu para pengambil keputusan dalam menentukan kategori desa mandiri berbasis posdaya.
\end{abstract}

Kata kunci: Sistem Pendukung Keputusan, Analitycal Hierarchy Process (AHP), Posdaya.

\begin{abstract}
The Millenium Development Goal's (MDG's), are eight international developments goals and many countries have agreed to achieve. The gools are eradicating poverty and hunger, achieving universal primary education for boys and girls, promoting gender equality, reducing child morality rates,improving maternal health, combating HIV/AIDS, malaria and other diseases, ensuring environmental sustainability and developing a global partnership for development. So the government plants to make a Family Empowering Post (Posdaya). The data collection is collected based on literature studies, observation and interview. And the data produce the criteria in the Posdaya. And the next, the criteria were given a comparative assessment by AHP (Analitycal Hierarchy Process) to find the prior weight with the assessment scale 1-9. The result of choosing the posdaya village showed that the aspect criteria of economy, education, health and environment are the main criteria to determine the village based posdaya. Built system can produce the assessment of independent village based on posdaya, on going posdaya, or without posdaya based on the last assessment for the system. So the system is expected to help the decision maker in choosing the category of independence village based on posdaya.
\end{abstract}

Kata kunci: Decision Support System, Analitycal Hierarchy Process (AHP), Posdaya.

\section{PENDAHULUAN}

1. 1. Latar Belakang

Millenium Development Goal's (MDG's), menyepakati delapan fokus pembangunan bagi negara-negara didunia yaitu penghapusan kemiskinan dan kelaparan. Tahun 2010 anak perempuan dan laki-laki mendapatkan pendidikan dasar penuh, mempromosikan kesetaraan dan kematian bayi dan balita, menurunkan angka kematian ibu, memerangi penyakit menular (TBC, HIV/AIDS, malaria dan penyakit menular lainnya). Menjamin keberlangsungan lingkungan hidup dan 
meningkatkan kerjasama global.

Pemanfaatan secara optimal modal ekonomi, modal budaya, modal sosial bagi pengembangan dan pemberdayaan keluarga dan masyarakat. Tumbuhnya pos pemberdayaan keluarga (POSDAYA) oleh masyarakat di desa akan menghasilkan manusia pembangun bagi diri keluarga dan masyarakat. Suatu desa dapat dikategorikan sebagai desa mandiri apabila ada sinergi, kolaborasi dan kerjasama program antar sektor, masyarakat dan pemerintah. Untuk mewujudkan tujuan desa yang mandiri dan makmur tersebut kegiatan difokuskan penyelesaian permasalahan yang bersentuhan dengan kondisi dan ketahanan keluarga dalam jangka pendek maupun panjang yaitu aspek pendidikan, ekonomi, kesehatan dan lingkungan budaya.

Untuk menilai apakah suatu desa dapat di kategorikan sebagai desa Posdaya atau belum maka perlu dilakukan penilaian dari beberapa indikator dan perlu dibangun sebuah sistem pendukung keputusan yang akan membantu penentuan desa berbasis Posdaya. Computer Based Information System (Sistem Informasi Berbasis Komputer) yang salah satunya adalah Sistem Pendukung Keputusan (Decission Support System) adalah suatu sistem informasi komputer yang interaktif dan dapat memberikan alternatif solusi bagi pembuat keputusan.

Berdasarkan dari latar belakang diatas, maka permasalahan yang akan diangkat dalam penelitian ini adalah "Sistem Pendukung Keputusan Penentuan Desa Posdaya dengan memanfaatkan model Analitycal Hierarchy Process (AHP).

\section{2. Rumusan Masalah}

Berdasarkan pada uraian diatas maka dipandang perlu adanya suatu sistem yang dapat memudahkan dan menyederhanakan pekerjaan dalam pengambilan keputusan untuk menentukan kelayakan suatu desa disebut desa mandiri berbasis posdaya. Sehingga disini perlu dibuat suatu desain dan implementasi Sistem Pendukung Keputusan untuk penentuan desa mandiri berbasis posdaya, rintisan posdaya atau belum adanya mandiri/posdaya.

\section{TUJUAN PENELITIAN}

Penelitian ini bertujuan untuk melakukan rancang bangun Sistem Pendukung Keputusan berbasis komputer untuk penentuan desa Posdaya dengan menggunakan model Analitycal Hierarchy Process (AHP) agar dapat dihasilkan suatu alternatif keputusan guna membantu pimpinan dalam pengambilan keputusan.

\section{MANFAAT PENELITIAN}

Hasil penelitian ini diharapkan dapat memberikan kontribusi instansi terkait dalam menentukan layak/tidaknya suatu desa menjadi desa mandiri berbasis posdaya. Selain itu dengan adanya sistem yang terkomputerisasi diharapkan adanya unsur obyektifitas pengambil keputusan serta dapat meminimalkan humam error, mempercepat proses pengolahan data proses pengambilan keputusan atau kebijakan pimpinan dalam penentuan desa yang belum adanya posdaya menjadi rintisan posdaya, dan pada akhirnya menjadi suatu desa mandiri berbasis posdaya.

\section{TINJAUAN PUSTAKA}

\section{1. Pos Pemberdayaan Keluarga (POSDAYA)}

Kegiatan pembentukan Posdaya yang diprakarsai oleh masyarakat ini harus didukung oleh semua pihak seperti pemerintah Provinsi dan atau Kabupaten/Kota. Adapun pemerintah desa sebagai ujung tombak untuk mendampingi masyarakat sebelum masyarakat mampu dan berdaya mengelola Posdaya secara mandiri dalam berbagai bentuk baik fasilitas, bimbingan dan dana. Salah satu tujuan Posdaya adalah mengajak masyarakat untuk membuka diri meningkatkan kemampuan, ketahanan dan akses terhadap komunikasi, informasi dan edukasi menuju kehidupan yang lebih baik di era globalisasi dan berbagai konsekwensinya. Fokus kegiatan dengan upaya peningkatan kualitas keluarga dari aspek pendidikan, ekonomi, lingkungan, sosial budaya dan kesehatan.

\section{2. Sistem Pendukung Keputusan}

Turban (2005) mendefinisikan SPK sebagai sistem informasi berbasis komputer yang adaptif, interaktif, fleksibel, yang secara khusus dikembangkan untuk mendukung solusi dari pemasalahan manajemen yang tidak terstruktur untuk meningkatkan kualitas pengambilan keputusan. Sistem Pendukung Keputusan (Decission Support System) adalah sistem informasi berbasis komputer yang menyediakan dukungan informasi yang interaktif bagi manajer dan 
praktisi bisnis selama proses pengambilan keputusan. Sistem Pendukung Keputusan menggunakan (1) model analitis, (2) database, (3) penilaian dan pandangan pembuat keputusan dan (4) proses pemodelan berbasis komputer yang interaktif untuk mendukung pembuatan keputusan bisnis yang semi terstruktur (O’Brien, 2005).

\section{METODE PENELITIAN}

5. 1. Metode Pendekatan

5.1.1. Metode Pengembangan Sistem

- Merancang, dan implementasi Sistem Pendukung Keputusan penentuan desa berbasis Posdaya.

- Menggunakan Pemodelan Analitycal Hierarchy Process (AHP) yaitu untuk pengambilan keputusan dengan banyak kriteria yang bersifat subjektif.

\subsubsection{Metode Prototyping}

Ada empat langkah metode prototyping yaitu :

- Pemilihan fungsi, mengacu pada pemilihan fungsi yang harus ditampilkan oleh prototyping. Pemilihan harus selalu dilakukan berdasarkan pada tugas-tugas yang relevan yang sesuai dengan permasalahan.

- Penyusunan Sistem Informasi, bertujuan untuk memenuhi permintaan akan tersedianya prototype

- Evaluasi

- Penggunaan sistem selanjutnya

\subsubsection{Perancangan Proses}

Untuk merancang proses dalam sistem pendukung keputusan digunakan DFD atau Data Flow Diagram. Dalam Smartdraw (2007), DFD dijelaskan sebagai a graphical illustration showing how data is processed by system in terms of inputs and output. DFD dikembangkan menjadi beberapa level, level yang paling atas disebut level-0 (diagram konteks).

\section{2. Metode Pengumpulan Data}

\subsubsection{Library Research}

Metode penelitian yang dilakukan dengan cara mempelajari bahan- bahan tertulis serta mengumpulkan data-data, browsing data via internet dan masalah-masalah berkaitan.

\subsubsection{Teknik Interview dan Observasi}

Pada metode ini peneliti mencari dan mengumpulkan data-data yang ada relevansinya dengan judul penelitian ini pada pihak terkait yaitu unit Penelitian dan Instansi yang terkait.

\subsubsection{Jenis dan Sumber Data}

Sumber data yang digunakan dalam penelitian ini adalah indikator-indikator yang ditetapkan untuk menjadi Posdaya yaitu aspek ekonomi, Pendidikan, Kesehatan dan lingkungan.

\section{HASIL DAN PEMBAHASAN}

\section{1. Uji Instrumen}

Variabel-variabel keputusaan yang dibutuhkan dalam penentuan Desa Mandiri berbasis Posdaya adalah : Pengembangan fungsi keagamaan, fungsi KB dan kesehatan, Fungsi pendidikan, Fungsi kewirausahaan/perekonomian, Fungsi lingkungan hidup yang memberi makna terhadap kehidupan keluarga yang bahagia dan sejahtera.

\section{2. Pemodelan SPK}

Model yang digunakan untuk menentukan kelayakan desa mandiri berbasis posdaya adalah Analytical Hierarchy Process (AHP). Pada perencanaan pemilihan desa mandiri dengan mengklasifikasikan variabel-variabel yang menentukan pengambilan keputusan kelayakan desa mandiri berbasis posdaya yaitu ekonomi, lingkungan, pendidikan dan kesehatan. Metode Analytical Hierarchy Process (AHP) yang diterapkan pada penentuan kelayakan dibatasi sampai dengan tingkat hirarki keempat. Masing-masing variabel/kriteria keputusan mempunyai kriteria intensitas (sub kriteria) yang didasarkan pada respon/penilaian masing-masing yang akan diberikan kepada desa mandiri. 
Empat kriteria ( Variabel) untuk model analisis penilian desa tersebut yaitu :

1. Ekonomi yaitu mempertimbangkan tingkat keuangan/ekonomi suatu desa. Kriteria ini memiliki sub-kriteria : Bawah, Menengah, Atas

2. Lingkungan yaitu mempertimbangkan tingkat kebersihan lingkungan suatu desa. Kriteria ini memiliki sub-kriteria : Bersih, Kurang Bersih, Kotor.

3. Pendidikan yaitu mempertimbangkan tingkat perbedaan pendidikan didalam suatu desa. Kriteria ini memiliki sub-kriteria : Tinggi, Sedang, Rendah

4. Kesehatan yaitu mempertimbangkan tingkat kesehatan suatu desa. Kriteria ini memiliki subkriteria : Baik, Kurang, Buruk.

Penentuan status untuk masing-masing kriteria dapat dibantu dengan melakukan survei, polling, yang akan di analisa. Selanjutnya sistem komputer menerima masukan data kondisi masing-masing sesuai dengan batasan intensitas kriteria (disebut juga Sub kriteria) yang telah ditetapkan diatas. Input data tersebut akan dijadikan basis data bagian perencanaan penentuan kelayakan desa mandiri.

Berikut ini adalah struktur hirarki AHP pada penentuan kelayakan desa mandiri berbasis posdaya dapat dilihat pada gambar 1 dibawah ini.

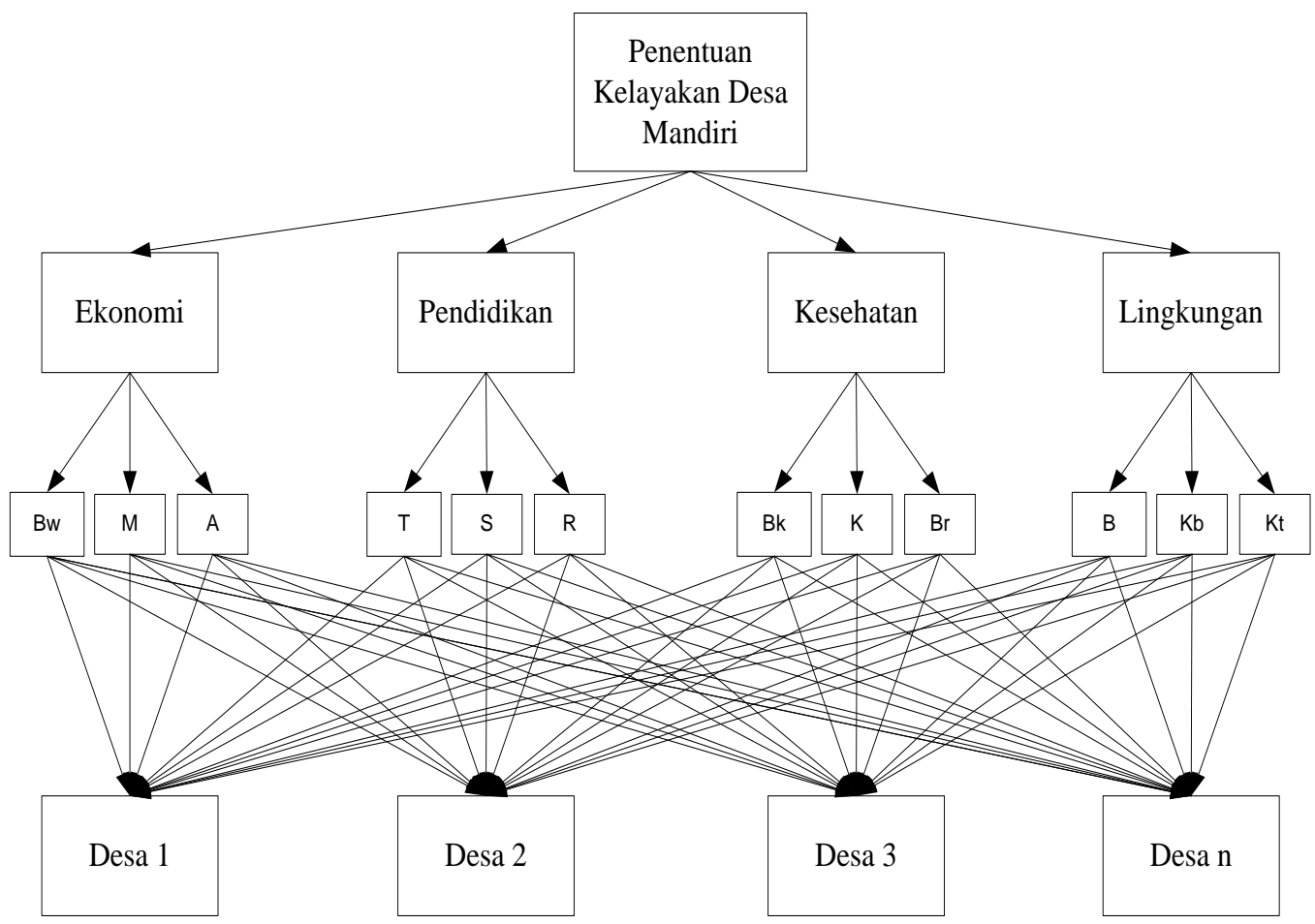

Gambar 1 Struktur hierarkhi AHP penentuan kelayakan desa mandiri berbasis posdaya

Keterangan :

$\begin{array}{lll}\text { Bw: Bawah } & \text { A : Atas } & \text { Kb : Kurang Bersih } \\ \mathrm{Kt}: \text { Kotor } & \mathrm{R}: \text { Rendah } & \mathrm{K}: \text { Kurang } \\ \mathrm{Br}: \text { Buruk } & \mathrm{B}: \text { Bersih } & \mathrm{M}: \text { Menengah } \\ \mathrm{T}: \text { Tinggi } & \mathrm{S}: \text { Sedang } & \mathrm{Bk}: \text { Baik }\end{array}$

\section{3. Penilaian Kriteria pada AHP}

Kriteria dan alternatif dinilai melalui perbandingan berpasangan. Menurut Saaty (1988), untuk berbagai persoalan, skala 1 sampai 9 adalah skala terbaik dalam mengekspresikan pendapat. Nilai dan definisi pendapat kualitatif dari skala perbandingan Saaty dapat dilihat pada tabel 1. 
Tabel 1. Skala penilaian perbandingan berpasangan

\begin{tabular}{|c|c|c|}
\hline $\begin{array}{l}\text { Intensitas dari } \\
\text { kepentingan pada } \\
\text { skala absolut }\end{array}$ & Definisi & Penjelasan \\
\hline 1 & Sama pentingnya & $\begin{array}{l}\text { Kedua aktifitas menyumbangkan } \\
\text { sama pada tujuan }\end{array}$ \\
\hline 3 & $\begin{array}{l}\text { Agak lebih penting yang satu atas } \\
\text { lainnya }\end{array}$ & $\begin{array}{l}\text { Pengalaman dan keputusan } \\
\text { menunjukkan kesehatanukaan atas } \\
\text { satu aktifitas lebih dari yang lain }\end{array}$ \\
\hline 5 & cukup penting & $\begin{array}{l}\text { Pengalaman dan keputusan } \\
\text { menunjukkan kesehatanukaan atas } \\
\text { satu aktifitas lebih dari yang lain }\end{array}$ \\
\hline 7 & sangat penting & $\begin{array}{l}\text { Pengalaman dan keputusan } \\
\text { menunjukkan kesehatanukaan yang } \\
\text { kuat atas satu aktifitas lebih dari } \\
\text { yang lain }\end{array}$ \\
\hline 9 & kepentingan yang ekstrim & $\begin{array}{l}\text { Bukti menyukai satu aktifitas } \\
\text { atas yang lain sangat kuat }\end{array}$ \\
\hline $2,4,6,8$ & $\begin{array}{l}\text { nilai tengah diantara dua nilai keputusan } \\
\text { yang berdekatan }\end{array}$ & Bila kompromi dibutuhkan \\
\hline Berbalikan & $\begin{array}{l}\text { jika aktifitas } \mathrm{i} \text { mempunyai nilai yang } \\
\text { lebih tinggi dari aktifitas j maka j } \\
\text { mempunyai nilai berbalikan ketika } \\
\text { dibandingkan dengan i }\end{array}$ & \\
\hline Rasio & $\begin{array}{l}\text { rasio yang didapat langsung dari } \\
\text { pengukuran }\end{array}$ & \\
\hline
\end{tabular}

\section{4. Penyajian Data}

\subsubsection{Sektor Pendidikan}

Dari data sektor pendidikan dapat disimpulkan bahwa sebagian besar penduduk desa tersebut pendidikannya sanagt minim dengan pendidikan tertinggi adalah SLTP. Selanjutnya akan diberi penilaian sebagai berikut :

Tabel 2. Penilaian sektor pendidikan

\begin{tabular}{|l|l|l|l|}
\hline No & Kriteria & Klasifikasi & Skor \\
\hline \multirow{4}{*}{1.} & \multirow{3}{*}{ Pendidikan } & Tinggi & $>=30$ \\
\cline { 3 - 4 } & & Sedang & $<30$ dan $>15$ \\
\cline { 3 - 4 } & Rendah & $<=15$ \\
\hline
\end{tabular}

\subsubsection{Sektor Perekonomian}

Dari data sektor perekonomian dapat disimpulkan bahwa sebagian besar penduduk desa tersebut adalah mata pencaharianya adalah buruh tani. Selanjutnya akan diberi penilaian sebagai berikut :

Tabel 3. Penilaian sektor perekonomian

\begin{tabular}{|l|l|l|l|}
\hline No & Kriteria & Klasifikasi & Skor \\
\hline \multirow{2}{*}{1} & \multirow{2}{*}{ Ekonomi } & Atas & $>=30$ \\
\cline { 3 - 4 } & & Menengah & $<30$ dan $>15$ \\
\hline
\end{tabular}


6.4.3.

\begin{tabular}{|l|l|l|}
\hline & Bawah & $<=15$ \\
\hline
\end{tabular}

Dari data sektor kesehatan dapat disimpulkan bahwa perhatian kesehatan kurang memadai. Selanjutnya akan diberi penilaian sebagai berikut:

Tabel 4. Penilaian sektor kesehatan

\begin{tabular}{|l|l|l|l|}
\hline No & Kriteria & Klasifikasi & Skor \\
\hline \multirow{4}{*}{1} & \multirow{3}{*}{ Kesehatan } & Baik & $>=30$ \\
\cline { 3 - 4 } & & Kurang & $<30$ dan $>15$ \\
\cline { 3 - 4 } & Buruk & $<=15$ \\
\hline
\end{tabular}

\subsubsection{Sektor Lingkungan Hidup}

Dari data sektor lingkungan dapat disimpulkan bahwa peran serta masyarakat sangat tinggi dalam menjaga lingkungan. Selanjutnya akan diberi penilaian sebagai berikut:

Tabel 5. Penilaian sektor lingkungan hidup

\begin{tabular}{|l|l|l|l|}
\hline No & Kriteria & Klasifikasi & Skor \\
\hline 1 & Lingkungan & Bersih & $>=30$ \\
\hline & & Kurang Bersih & $<30$ dan $>15$ \\
\hline & & Kotor & $<=15$ \\
\hline
\end{tabular}

Pada semua sektor dinilai melalui perbandingan berpasangan. Menurut Saaty (1988), untuk berbagai persoalan, skala 1 sampai 9 adalah skala terbaik dalam mengekspresikan pendapat.

\section{5. Analisis Data}

Selanjutnya hasil survei pada desa tersebut akan dilakukan perhitungan menggunakan model perhitungan AHP. Penilaian kriteria dan alternatif dinilai melalui perbandingan berpasangan. Menurut Saaty (1988), untuk berbagai persoalan, skala 1 sampai 9 adalah skala terbaik dalam mengekspresikan pendapat.

Tabel 6. Matrix Perbandingan Pasangan Hasil Survei

\begin{tabular}{|c|c|c|c|c|}
\hline GOAL & Lingkungan & Kesehatan & Pendidikan & Ekonomi \\
\hline Lingkungan & 1 & 5 & $1 / 3$ & $1 / 4$ \\
\hline Kesehatan & $1 / 5$ & 1 & $1 / 7$ & $1 / 8$ \\
\hline Pendidikan & 3 & 7 & 1 & $1 / 2$ \\
\hline Ekonomi & 4 & 8 & 2 & 1 \\
\hline Jumlah & 8.2 & 21 & 3.476 & 1.875 \\
\hline
\end{tabular}

Jumlah pertanyaan perbandingan berpasangan adalah $n(n-1) / 2$ karena saling berbalikan dan diagonalnya selalu bernilai satu.

Tabel 7. Bobot Relatif dan Eigen Vektor Utama

\begin{tabular}{|l|c|c|c|c|c|}
\hline \multicolumn{1}{|c|}{ GOAL } & Lingkungan & Kesehatan & Pendidikan & Ekonomi & Eigenvector \\
\hline Lingkungan & 0.12195 & 0.23810 & 0.09589 & 0.13333 & 0.14732 \\
\hline Kesehatan & 0.02439 & 0.04762 & 0.04110 & 0.06667 & 0.04494 \\
\hline Pendidikan & 0.36585 & 0.33333 & 0.28767 & 0.26667 & 0.31338 \\
\hline Ekonomi & 0.48780 & 0.38095 & 0.57534 & 0.53333 & 0.49436 \\
\hline
\end{tabular}




\begin{tabular}{|l|l|l|l|l|l|}
\hline Jumlah & 1 & 1 & 1 & 1 & 1 \\
\hline
\end{tabular}

Tabel di atas merupakan hasil perhitungan bobot relatif yang dinormalkan dari contoh di tabel 6 . Eigen vektor utama yang tertera pada kolom terakhir tabel 3 didapat dengan merata-rata bobot relatif yang dinormalkan pada setiap baris.

Konsistensi AHP

1. Menghitung nilai eigen maksimum

$$
\begin{aligned}
\lambda \text { maksimum } & =8.2 \times 0.14732+21 \times 0.04494+3.47619 \times 0.31338+1.875 \times 0.49436 \\
& =4.16810
\end{aligned}
$$

2. Menghitung indeks konsistensi

$$
\begin{aligned}
& \text { Dimana : } \\
& \begin{array}{l}
\text { C.I } \\
\lambda \text { maksimum } \quad=\text { Nilai eigen terbesar dari matrik berordo } \mathrm{n}
\end{array}
\end{aligned}
$$

$$
C . I=\frac{\lambda \text { maksimum }-\mathbf{n}}{n-1}
$$

Karena matrix berordo 4 (yakni terdiri dari 4 faktor), nilai indek konsistensi yang diperoleh:

$$
\begin{aligned}
& C . I=\frac{416810-1}{4-1} \\
& C . I=0,05603
\end{aligned}
$$

3. Perhitungan Consistency Rasio

Apabila C.I bernilai nol, berarti matrik konsisten. batas ketidakkonsistensi yang ditetapkan Saaty, diukur dengan menggunakan Rasio Konsistensi (CR), yakni perbandingan indek konsistensi dengan nilai pembangkit random (RI) yang ditabelkan dalam tabel 4. Nilai ini bergantung pada ordo matrik n. Dengan demikian, Rasio konsistensi dapat dirumuskan:

$$
C . R=\frac{\text { C.I }}{R \cdot I .}
$$

Tabel 8. Nilai Pembangkit Random (R.I.)

\begin{tabular}{|c|c|c|c|c|c|c|c|c|c|c|}
\hline $\mathrm{n}$ & 1 & 2 & 3 & 4 & 5 & 6 & 7 & 8 & 9 & 10 \\
\hline RI. & 0 & 0 & 0.58 & 0.9 & 1.12 & 1.24 & 1.32 & 1.41 & 1.45 & 1.49 \\
\hline
\end{tabular}

$$
\begin{aligned}
& C . R=\frac{0,05603}{0,9} \\
& C . R=0,06226
\end{aligned}
$$

\section{6. Kriteria/Variabel Penilaian}

Pada setiap variabel mempunyai lima indikator sebagai bahan pendukung keputusan dalam menentukan golongan dari variabel tersebut. Indikator tersebut merupakan sebuah penilaian dari kondisi suatu desa tertentu. Dalam penilaiannya, setiap indikator mempunyai nilai range antara 1 9. Dan nilai 0 bila suatu desa tidak memenuhi indikator yang terkait. Jadi penilaian variabel pada suatu desa adalah sebagai berikut :

Tabel 9. Kriteria Penilaian

\begin{tabular}{|l|c|c|c|c|}
\hline No & Kriteria & Keterangan & Skor Min & Skor Max \\
\hline \multirow{4}{*}{1} & \multirow{3}{*}{ Ekonomi } & Indikator 1 & 0 & 9 \\
\cline { 3 - 5 } & & Indikator 2 & 0 & 9 \\
\cline { 3 - 5 } & & Indikator 3 & 0 & 9 \\
\cline { 3 - 5 } & & Indikator 4 & 0 & 9 \\
\cline { 3 - 5 } & & Indikator 5 & 0 & 9 \\
\hline \multicolumn{2}{|c|}{ Jumlah } & 0 & 45 \\
\hline
\end{tabular}




\begin{tabular}{|l|c|c|c|c|}
\hline No & Kriteria & Keterangan & Skor Min & Skor Max \\
\hline \multirow{4}{*}{2} & \multirow{4}{*}{ Pendidikan } & Indikator 1 & 0 & 9 \\
\cline { 3 - 5 } & & Indikator 2 & 0 & 9 \\
\cline { 3 - 5 } & & Indikator 3 & 0 & 9 \\
\cline { 3 - 5 } & & Indikator 4 & 0 & 9 \\
\cline { 3 - 5 } & Indikator 5 & 0 & 9 \\
\hline \multicolumn{2}{|r}{ Jumlah } & 0 & 45 \\
\hline
\end{tabular}

\begin{tabular}{|l|c|c|c|c|}
\hline No & Kriteria & Keterangan & Skor Min & Skor Max \\
\hline \multirow{3}{*}{3} & \multirow{4}{*}{ Lingkungan } & Indikator 1 & 0 & 9 \\
\cline { 3 - 5 } & Indikator 2 & 0 & 9 \\
\cline { 3 - 5 } & & Indikator 3 & 0 & 9 \\
\cline { 3 - 5 } & & Indikator 4 & 0 & 9 \\
\cline { 3 - 5 } & & Indikator 5 & 0 & 9 \\
\hline \multicolumn{2}{|c|}{ Jumlah } & 0 & 45 \\
\hline
\end{tabular}

\begin{tabular}{|l|c|c|c|c|}
\hline No & Kriteria & Keterangan & Skor Min & Skor Max \\
\hline \multirow{4}{*}{4} & \multirow{3}{*}{ Kesehatan } & Indikator 1 & 0 & 9 \\
\cline { 3 - 5 } & Indikator 2 & 0 & 9 \\
\cline { 3 - 5 } & & Indikator 3 & 0 & 9 \\
\cline { 3 - 5 } & & Indikator 4 & 0 & 9 \\
\cline { 3 - 5 } & & Indikator 5 & 0 & 9 \\
\hline \multicolumn{2}{|c|}{ Jumlah } & 0 & 45 \\
\hline
\end{tabular}

Tabel 10. Klasifikasi variabel

\begin{tabular}{|c|c|c|c|}
\hline No & Kriteria & Klasifikasi & Skor \\
\hline \multirow{3}{*}{1} & \multirow{3}{*}{ Ekonomi } & Atas & $>=30$ \\
\hline & & Menengah & $<30$ dan $>15$ \\
\hline & & Bawah & $<=15$ \\
\hline \multirow{3}{*}{2} & \multirow{3}{*}{ Pendidikan } & Tinggi & $>=30$ \\
\hline & & Sedang & $<30$ dan $>15$ \\
\hline & & Rendah & $<=15$ \\
\hline \multirow{3}{*}{3} & \multirow{3}{*}{ Lingkungan } & Bersih & $>=30$ \\
\hline & & Kurang Bersih & $<30$ dan $>15$ \\
\hline & & Kotor & $<=15$ \\
\hline \multirow{3}{*}{4} & \multirow{3}{*}{ Kesehatan } & Baik & $>=30$ \\
\hline & & Kurang & $<30$ dan $>15$ \\
\hline & & Buruk & $<=15$ \\
\hline
\end{tabular}

Tabel 11. Klasfikasi Nilai

\begin{tabular}{|c|c|}
\hline Kategori & Nilai \\
\hline Mandiri & $>=7.5$ \\
\hline Rintisan Mandiri & $<7.5$ \\
\hline Belum Mandiri & $<5$ \\
\hline
\end{tabular}

\section{7. Implementasi Sistem Pendukung Keputusan}

Dari hasil perhitungan analisis data tersebut diatas, selanjutnya akan dibuat dengan perhitungan menggunakan sistem pendukung keputusan berbasis komputerisasi.

\subsubsection{Komponen SPK}

Sumber data Internal terdiri dari :

1. Kondisi bidang Ekonomi

2. Kondisi bidang Pendidikan 
3. Kondisi bidang Lingkungan

4. Kondisi bidang Kesehatan

Berikut ini ádalah diagram arsitektur SPK untuk menentukan kelayakan Desa Mandiri berbasis Posdaya dapat dilihat pada gambar 2 di bawah ini.

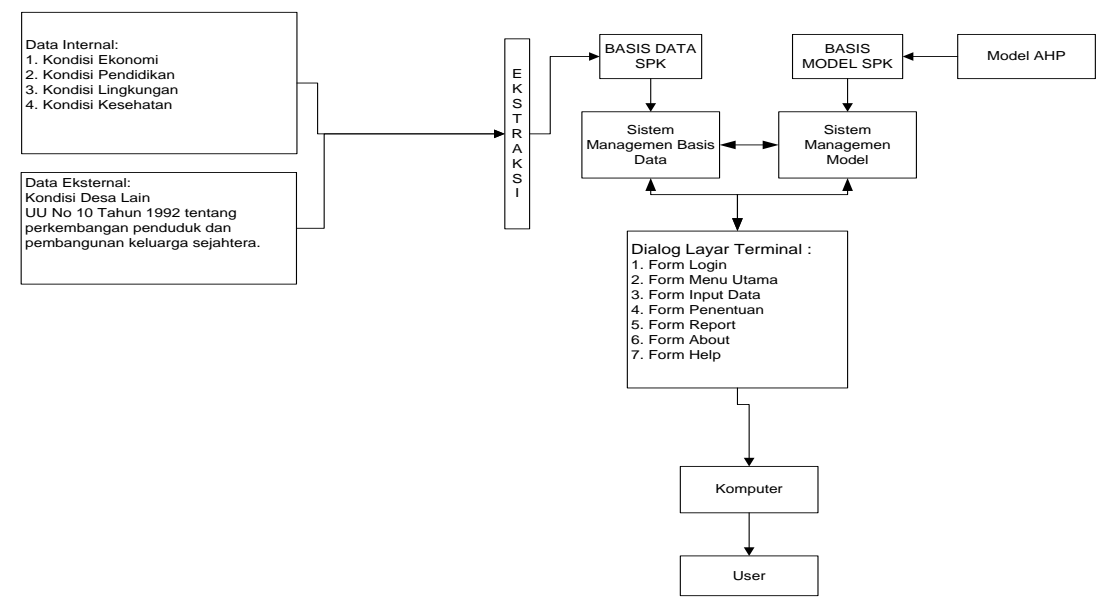

Gambar 2. Arsitektur SPK untuk menentukan kelayakan

\section{Desa Mandiri berbasis Posdaya}

\subsubsection{Tampilan Aplikasi SPK}

SPK untuk menentukan kelayakan desa mandiri berbasis posdaya ini dirancang dengan menggunakan bahasa pemrograman Microsoft Visual Studio 2008. Sedangkan untuk pembuatan databasenya bisa dengan menggunakan fasilitas yang ada di Microsoft Acces.

\section{- Halaman Startup}

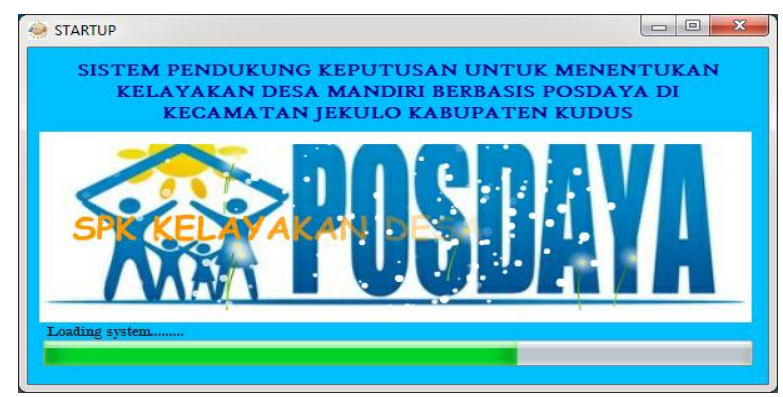

Gambar 3. Form Startup

Pada form Login USER harus memasukkan nama user (Username) dan Password untuk masuk ke halaman utama program DSS Penentuan Desa Mandiri Berbasis Posdaya.

- Halaman Utama Program SPK Penentuan Desa Mandiri Berbasis Posdaya.

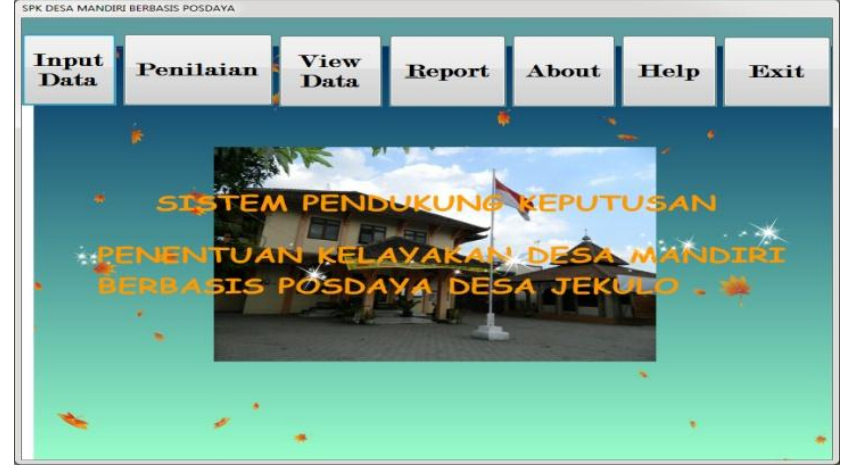

Gambar 4. Form Utama (Home Page) 
Pada halaman utama ini terdapat beberapa pilihan seperti yang terlihat pada menu utama.

\section{KESIMPULAN}

Dari hasil penelitian SPK untuk menentukan kelayakan desa mandiri berbasis posdaya dapat diambil beberapa kesimpulan sebagai berikut :

1. Analitycal Hierarchi Proses (AHP) dapat digunakan dalam pembuatan sistem pendukung keputusan untuk menentukan kelayakan desa berbasis posdaya.

2. Penentuan prioritas kepentingan pada setiap kriteria dapat berubah sesuai kondisi yang berlaku.

3. Berdasarkan survei pada responden dapat diketahui prioritas kepentingan pada penentuan desa mandiri pada saat ini adalah faktor ekonomi kemudian pendidikan dan disusul lingkungan dan kesehatan.

\section{DAFTAR PUSTAKA}

[1] Badan Pusat Statistik dan Departemen Sosial. 2002. Penduduk Fakir Miskin Indonesia 2002. Jakarta.

[2] Daihani, D.U, 2001, Komputerisasi Pengambilan Keputusan, Elex Media Komputindo, Kelompok Gramedia, Jakarta.

[3] Fiati, R., Inayati.,N., (2011), SPK Penentuan Kelayakan Sekolah Berbasis Internasional (SBI), Universitas Muria Kudus

[4] Fiati, R.,Khotimah,T., (2012), Pemanfaatan AHP sebagai model SPK Penentuan Desa Posdaya, Universitas Muria Kudus

[5] Finlay, P.N. 2003. Introducing Decision Support System. Oxford, UK Cambridge, Mass.,NCC Blackwell; Blackwell Publishers.

[6] Haeruman, Herman JS dan Eriyatno. 2001. Kemitraan dalam Pengembangan Ekonomi Lokal. Yayasan Mitra Pembangunan Desa-Kota dan Busines Inovation Centre Indonesia. Jakarta.

[7] Indrajit, R.E., 2001, Pengantar Konsep Dasar : Manajemen Sistem Informasi dan Teknologi Informasi, Elex Media Komputindo, Kelompok Gramedia, Jakarta.

[8] McLeod, R. Jr. and George Schell, 2001, Management Information System, 8thEdition, Prentice Hall. Inc, New Jersey.

[9] Pressman, R.S., 2002, Rekayasa Perangkat Lunak, Pendekatan Praktisi (Buku Satu), Andi, Yogyakarta.

[10] Saaty, T.L., 1990, The Analytic Hierarchy Process, Mc.Graw-Hill, New York

[11] Silberschatz, A., and Henry F. Korth., 2002, Database System Concepts, ${ }^{\text {th }}$ Edition, McGraw Hill International Co., New York.

[12] Sukerti, N.K., 2010, SPK Penentuan Desa Penerima Bantuan Program Community Based Development (CBD) Bali Sejahtera menggunakan Metode TOPSIS, Tesis, Magister Ilmu Komputer, Program Pascasarjana, Universitas Muria Kudus, Yogyakarta.

[13] Turban, E., and Aronson, J.E., 2001, Decission Support System and Intelligent System, $6^{\text {th }}$ Edition, Prentice Hall, Inc., New Jersey.

[14] Sumber Internet : www.bps.org 